\title{
Asia Treads the Nuclear Path, Unaware That Self- Assured Destruction Would Result from Nuclear War
}

\section{OWEN B. TOON, ALAN ROBOCK, MICHAEL MILLS AND LILI XIA}

$\mathrm{O}^{\prime}$

THE NINE COUNTRIES known to have nuclear weapons, six are located in Asia and another, the United States, borders the Pacific Ocean. Russia and China were the first Asian nations with nuclear weapons, followed by Israel, India, Pakistan, and North Korea. Most of the world's nuclear powers are reducing their arsenals or maintaining them at historic levels, but several of those in Asia-India, Pakistan, and North Koreacontinue to pursue relentless and expensive programs of nuclear weapons development and production. Hopefully, the nuclear agreement reached in July 2015 between Iran, the European Union, and the five permanent members of the United Nations Security Council will be a step toward eliminating nuclear weapons throughout Asia and the rest of the world. As we will discuss below, any country possessing a nuclear arsenal is on a path leading toward self-assured destruction, and is a threat to people everywhere on Earth.

Nuclear-armed countries are a threat to people everywhere partly because of the destructive power of single weapons - one weapon is enough to destroy a small cityand partly because of the growing ability of nations to launch missiles across the globe. Nuclear powers such as India and North Korea, the latter of which is thought currently to have a very small nuclear capability that is not in the form of useful weapons, are working on the means to deliver weapons globally. Each has capabilities now to launch weapons from submarines, and both are working on intercontinental ballistic missiles. India has already launched satellites to the moon and Mars, but these missiles are not thought to be suitable for India's current nuclear warheads.

However, it is not just the brute force attack, which kills people in the geographically limited target zone, that threatens people everywhere. Most people have forgotten nuclear winter. Many think that the theory was disproven, or that the end of the nuclear arms race and the subsequent reduction of Russian and American nuclear arsenals eliminated the dangers of global nuclear war. But they are wrong. Nuclear winter is an assault on the global climate system caused by smoke from fires ignited by the bombs. As the smoke rapidly spreads globally in the stratosphere, it will reduce temperatures and rainfall and destroy the global ozone layer, which shields us from harmful ultraviolet radiation from the sun. Recently it has been shown that even the smoke created by the use of

Owen B. Toon (toon@lasp.colorado.edu) is Professor of Atmospheric and Oceanic Sciences at the University of Colorado, Boulder. Alan Robock (robock@envsci.rutgers.edu) is Distinguished Professor of Environmental Sciences at Rutgers University. Michael Mills (mmills@ucar.edu) is Research Scientist at the U.S. National Center for Atmospheric Research. Lili Xia (lxia@ envsci.rutgers.edu) is Postdoctoral Researcher in Environmental Sciences at Rutgers University. 
100 weapons of the size used on Hiroshima in the Second World War, comparable to the arsenals of India or Pakistan, could cause environmental damage that would extend globally, threatening the world food supply and creating mass starvation worldwide (Mills et al. 2014; Özdoğan, Robock, and Kucharik 2013; Robock and Toon 2012; Xia and Robock 2013; Xia et al. 2015). The effects of food loss would also be felt in the aggressor nation. Hence, being a nuclear aggressor is suicidal, and destruction is self-assured. The deaths from these environmental changes would likely be a factor of ten or more larger than the direct casualties from the explosions-potentially threatening the bulk of the human population - and would not be limited to the combatants.

The acquisition of nuclear weapons may initially be driven by military considerations, and primarily involve a nation's scientists and engineers. However, the reasons for having nuclear arsenals go far beyond defensive needs or scientific and engineering capability. The rationale for nuclear weapons touches on politics, economics, cultural identity, religion, and many other aspects of human society. As a result, reducing nuclear arsenals requires political, cultural, and other changes that in turn demand contributions from many sectors of society and potentially the entire populations of countries with arsenals.

The primary reason cited by nations for building an arsenal is national protection. For example, the United States argued that it needed to develop nuclear weapons to be prepared in case Germany developed them during World War II. Once it had nuclear weapons, the United States argued that it needed to use them in the first nuclear war, World War II, to save the lives of large numbers of allied military personnel who might otherwise have died invading Japan. Like dominoes falling, Russia argued that it needed nuclear weapons to protect itself against the United States and other Western nations. Similar arguments were made by China and North Korea. India may have built weapons initially as a counter to China, while Pakistan built them to counter India. Israel built them to defend itself from surrounding hostile states. The concept of mutual assured destruction (MAD) lies at the heart of using nuclear weapons for national protection. Under MAD, it is assumed that an aggressor will not attack you because they fear nuclear retaliation.

Protection from potential enemies is not the only reason that nuclear arsenals have been built, however. As discussed by Tim Oakes and Emily Yeh in this volume, a wide variety of people are involved in understanding catastrophes within Asia. Some insight into reasons for building nuclear arsenals comes from critical self-examinations by Indian and Pakistani intellectuals_-including journalists, scientists, social psychologists, filmmakers, and poets - and schoolchildren, among others, in the aftermath of the nuclear tests by India and Pakistan in 1998, perhaps stirred by the conflict between the peaceful resistance image of Mahatma Gandhi and nuclear weapons (Kothari and Mian 2001). Analytical studies of India's motivations for having a nuclear arsenal have been discussed by historians, political scientists, defense analysts, and others (e.g., SarDesai and Thomas 2002).

One reason, discussed in these works, for having a nuclear arsenal is the demonstration of scientific and technical capability in order to enhance national image. Another set of reasons for having a nuclear arsenal is to be seen as a major power in the world, to prevent current nuclear states from meddling in your affairs, and to take a place in world decision-making. For instance, the first five nuclear nations - the United States, the United Kingdom, the Soviet Union (now Russia), France, and China (the P5)—are 
the permanent members of the UN Security Council, but now India, with a significant fraction of the world's population, wants a seat. Many nations have a desire to be freed from external interference in internal affairs. This latter rationale is particularly important to many countries. For example, Indian writers cite US President Richard Nixon sending an aircraft carrier into the Bay of Bengal during the 1971 conflict between India and Pakistan as interference and favoritism of Western Pakistan that should be prevented in the future. Another goal is to obtain freedom of action that is external to the country. The idea is that nuclear states can do whatever they please, because other states would be afraid of triggering a nuclear response if they resist. Sagan (2012), following earlier insights by others, pointed out that soon after Pakistan tested its first nuclear weapon in 1998 it invaded part of Kashmir, apparently under the mistaken assumption that India would not counter the invasion for fear of triggering a nuclear response. At the time, there were threats and counter-threats between Pakistan and India concerning the use of nuclear weapons. However, India did repel the Pakistani invasion. The recent Russian annexation of Crimea, and its potential expansion across other former Soviet states, may involve a similar assumption that the rest of the world will be afraid to respond because of the possibility of triggering a nuclear conflict.

The Cold War nuclear standoff between the West and the East, which was based on MAD, may be slowly evolving into a nuclear free-for-all (e.g., Evans 2014). Former US Secretaries of State George Shultz and Henry Kissinger, former US Secretary of Defense William Perry, and former US Senator Sam Nunn founded the Nuclear Security Project, "an effort to galvanize global action to reduce urgent nuclear dangers and build support for reducing reliance on nuclear weapons, ultimately ending them as a threat to the world" (Nuclear Security Project, n.d.). These warriors of the Cold War argue in a series of editorials in the Wall Street Journal that in a world with many nuclear powers, each capable of destroying any country on Earth, and terrorist groups with increasing potential to gain control of nuclear weapons, MAD no longer works and one can no longer assume that peace can be maintained through rational analysis, careful control of weapons, or successful negotiation between well-defined states with clear national interests. The only solution, they argue, is to create a world without nuclear weapons (Shultz et al. 2007, 2008, 2010, 2011).

While most of us are oblivious to the power of the arsenals of India and Pakistan, they are, in fact, at the levels of the Soviet Union and the Western powers in the early 1950s. If the weapons were used, they could destroy a large fraction of the infrastructure of any country on Earth. India, North Korea, and Iran are developing ballistic weapons-delivery systems that can send nuclear warheads over intercontinental scales. In the coming decades, it is possible that there will be a global nuclear gridlock caused by multiple nuclear-armed Asian, American, and European states, each with differing goals and aspirations, and each with the capability to purposefully destroy any adversary and to inadvertently destroy much of the rest of the world.

Against this backdrop of expanding nuclear states, the concept of self-assured destruction (SAD) has been introduced (Robock and Toon 2012). According to this concept, it is suicidal to use nuclear weapons, even the not-so-modest arsenals of Pakistan and India. Everyone recognizes that immense damage and loss of life will occur in the combatant countries due to the explosions of the weapons. However, it is not as well understood that worldwide environmental damage from even a regional conflict could 
be much worse than the direct effects of the explosions. The fires started from weapons exploding in cities will flood the upper atmosphere with smoke. Smoke absorbs sunlight, heating the upper atmosphere and destroying the protective ozone layer. The lightabsorbing smoke also prevents sunlight from reaching the Earth's surface, driving global temperatures down enough to damage agriculture at mid-latitudes. The loss of agricultural productivity will create mass starvation globally, including in those countries that used the nuclear weapons. To reiterate, the deaths from these environmental changes would likely be a factor of ten or more larger than the direct casualties from the explosions - potentially threatening the bulk of the human population-and would not be limited to the combatants.

\section{How Do Asian Arsenals Compare with Others?}

Figure 1 illustrates the history of the number of warheads on the planet, and those in Russia and the United States, which currently control more than 90 percent of the weapons (Kristensen and Norris 2014). The world total peaked at around 70,000

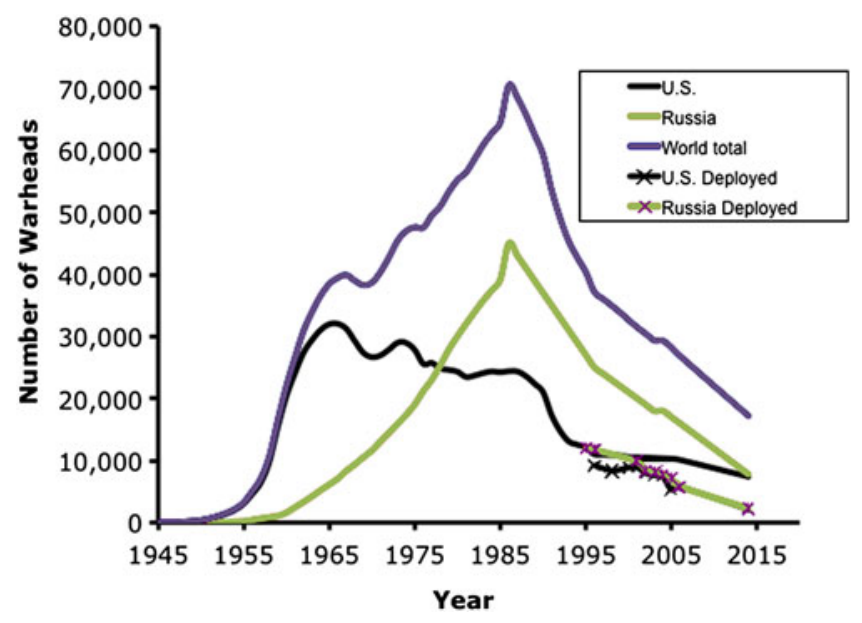

Figure 1. The number of nuclear warheads since World War II based on data from Kristensen and Norris (2013). Shown are the arsenals of the United States, Russia, and the world. After about 2000, Russia and the United States began to base treaties on the number of deployed strategic warheads, rather than the total number of warheads. Deployed strategic warheads are shown with symbols. In 2013 , there were about 16,300 warheads in the world. About 6,200 of these were retired and ostensibly waiting to be destroyed. The United States and Russia had about 3,750 deployed strategic warheads, which are covered by treaties negotiated under the Bush and Obama administrations. Another 5,380 warheads were in storage, or considered not to be strategic, and therefore not covered in recent treaties. 
warheads in 1986, five years before the disintegration of the Soviet Union. The downward trend in nuclear weapons begun in 1986 has continued to this day, with the 2014 world arsenal being near 16,000 weapons, about 23 percent of the peak in 1986. The Strategic Offensive Reductions Treaty (SORT) reached by Presidents George W. Bush and Vladimir Putin, and in place from 2003 to 2011, regulated the number of strategic warheads to not exceed 1,700 to 2,200 for each country by December 31, 2012. The New Strategic Arms Reduction Treaty (New-START), developed under Presidents Barack Obama and Dmitry Medvedev and in place after 2011, results in similar numbers of deployed strategic warheads as in the SORT. Certain types of warheads were not counted in either the SORT or New-START. Of the 16,000 total warheads believed to exist among all nuclear powers, only about 3,750 deployed strategic weapons are regulated under New-START. The remainder includes about 7,000 weapons waiting to be dismantled in the United States and Russia, and more than 5,000 weapons in the United States and Russia that are not considered deployed or strategic (many are strategic warheads in storage, others are tactical weapons). Both Russia and the United States are embarked on expensive upgrades to their nuclear capabilities.

Figure 2 outlines the history of nuclear proliferation. Up until the mid-1980s, about one new nuclear state appeared every five years. Following the start of the build-down of nuclear weapons by the United States and Russia in 1986, a number of states abandoned their arsenals or stopped nuclear weapons programs that were under consideration or development. South Africa developed a small nuclear arsenal and then abandoned it in the 1990s, the only country to ever abandon a self-developed nuclear arsenal. A number of countries inherited nuclear weapons from the former Soviet Union, but gave them up, including Kazakhstan in Asia, as well as Belarus and Ukraine in Europe.

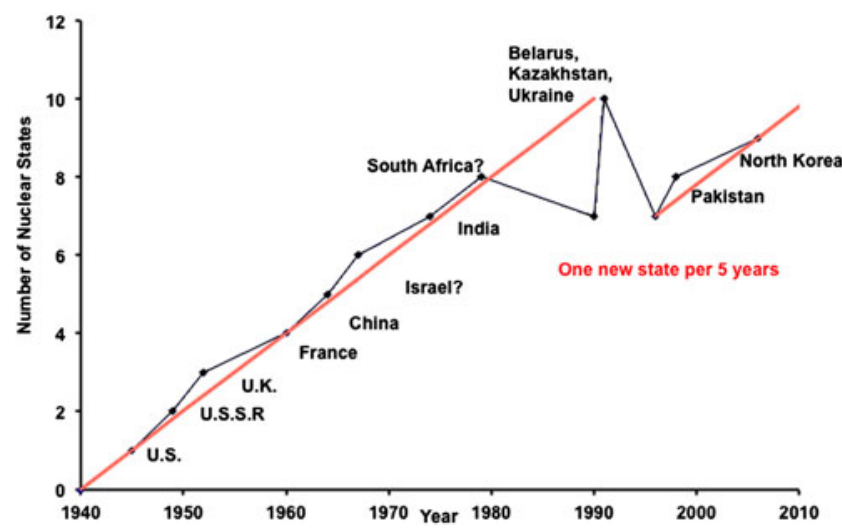

Figure 2. The dates when various nations obtained a nuclear warhead, mainly based on when they first tested a weapon. For Israel and South Africa, the evidence for tests is controversial, so an estimate for when they had a useable weapon is given. Belarus, Kazakhstan, and Ukraine inherited weapons from the Soviet Union and transferred them to Russia in the 1990s. South Africa gave up its weapons in the 1990s. The straight lines represent one new nuclear state every five years. 


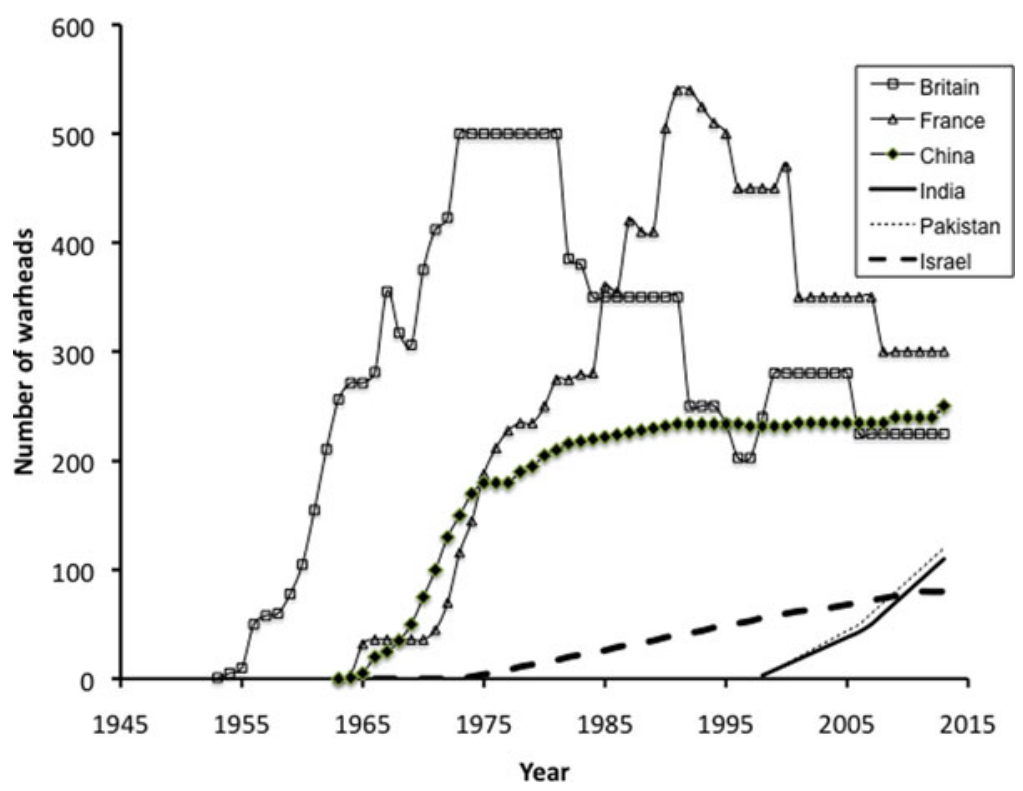

Figure 3. The number of warheads thought to be in the arsenals of Britain, France, China, India, Pakistan, and Israel based on data from Kristensen and Norris (2013). North Korean weapons are not shown because it is uncertain that it has an arsenal of useable weapons.

Unfortunately, proliferation was renewed in 1998 when India and then Pakistan tested nuclear weapons. As figure 2 indicates, the world now may be back on the trend of one new nuclear state about every five years.

Figure 3 illustrates the arsenals of the countries with nuclear weapons other than the United States and Russia (Kristensen and Norris 2013). It is very difficult to determine the numbers of weapons in most of these countries. While Britain and France have been slowly reducing their arsenals, and China seems to have maintained a constant level, Pakistan, India, and possibly Israel seem to be increasing their arsenals. The yields of the weapons in most of the programs are not known. Britain, France, and China have weapons with yields above 100 kilotons $;^{1}$ however, it is likely, based on their nuclear tests, that India and Pakistan have weapons with yields similar to those of the US weapons used in World War II, around 10-20 kilotons, or even less.

In contrast to some parts of Asia where nuclear proliferation and arsenal growth are occurring, much of the world is ridding itself of nuclear weapons. Figure 4 shows the history of the development of Nuclear-Weapon-Free Zones. Almost one-third of the

\footnotetext{
${ }^{1}$ The explosive energy released in a nuclear detonation is measured in relation to an explosion of the equivalent weight of the conventional explosive trinitrotoluene-TNT. The explosive power in the total of all bombs used in World War II, including the atomic bombs dropped on Hiroshima and Nagasaki, was several megatons, which could now be released by just one high-yield nuclear weapon.
} 


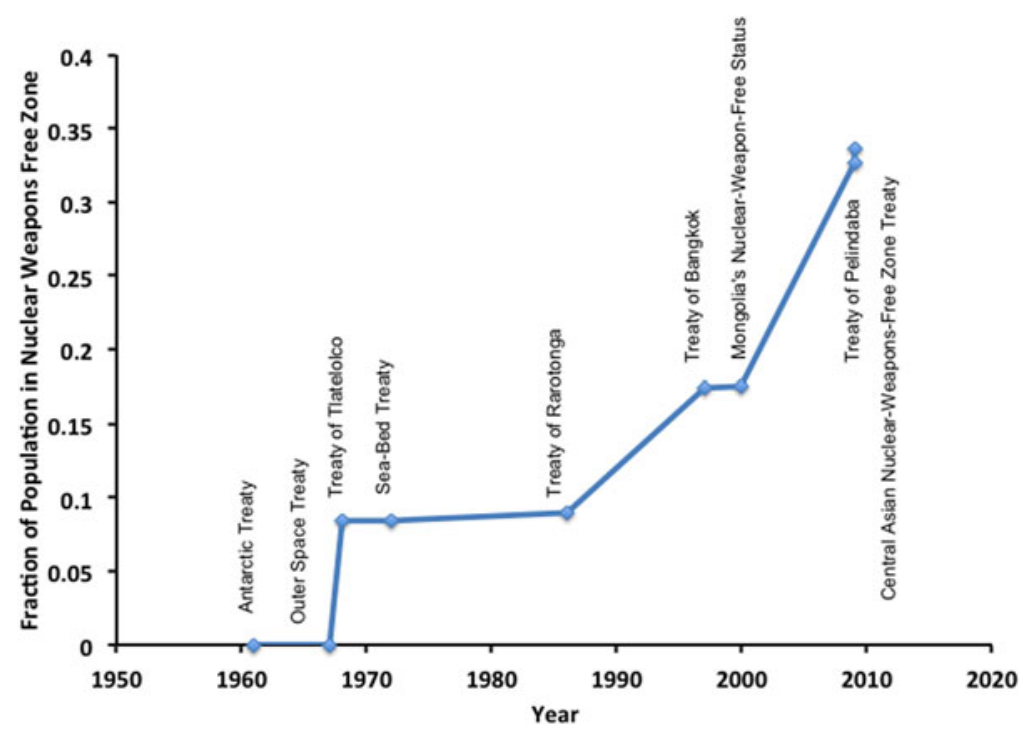

Figure 4. The fraction of the world's current population that lives in Nuclear-Weapon-Free Zones, as recognized through UN treaties. Currently about one-third of Earth's population lives in a nuclear-free zone.

human population now lives in regions in which the United Nations has recognized treaties banning nuclear weapons. The Treaty for the Prohibition of Nuclear Weapons in Latin America and the Caribbean, also known as the Treaty of Tlatelolco, went into effect in 1968, and was eventually signed by all thirty-three independent nations of Latin America and the Caribbean, including Cuba. However, Brazil and Argentina reserved the right to conduct "peaceful nuclear weapons explosions," and islands such as Puerto Rico, British Virgin Islands, and Guadeloupe, associated with Nuclear Weapons States, are excluded. Africa established a Nuclear-Weapon-Free Zone under the Treaty of Pelindaba, which took effect in 2009. As a result of the additional treaties for Antarctica and the Rarotonga Treaty-involving Australia, New Zealand, and a number of island nations in the Pacific - the entire Southern Hemisphere (with the exception of islands associated with states with nuclear weapons and international waters) is a Nuclear-Weapon-Free Zone. The Association of Southeast Asian Nations, including Brunei Darussalam, Cambodia, Indonesia, Laos, Malaysia, Myanmar, Philippines, Singapore, Thailand, and Vietnam, became a Nuclear-Weapon-Free Zone in 1997 under the Bangkok Treaty. There is also a Central Asian nuclear-free treaty signed by Kazakhstan, Kyrgyzstan, Tajikistan, Turkmenistan, and Uzbekistan, which entered into force in 2009. Mongolia declared itself a Nuclear-Weapon-Free Zone in 1992, and it was formally recognized as a Nuclear-Weapon-Free Zone in 2012 by the five original Nuclear Weapons States: the United States, China, France, the United Kingdom, and Russia. In total there are at least sixteen countries in Asia that are free of nuclear weapons, which is almost three times as many as Asian Nuclear Weapons States. 


\section{How Many Weapons Are Enough?}

A comparison of figure 1 and figure 3 raises the question-how do you know how many weapons are enough? None of the Nuclear Weapons States has stated its criteria for answering this question.

In the case of the United States, analyses in the late 1940s reported by Eden (2004) identified militarily important industrial sites for the Soviet Union and concluded that these could be destroyed by the delivery of 100 atomic weapons, which were similar in yield to the weapons in the arsenals of present-day Pakistan, India, and North Korea. Of course, weapons may not explode, or may never reach their target, so it was estimated that 200 weapons would be needed for the United States to destroy the Soviet Union. Despite this estimate, the US arsenal rose to more than 150 times this many weapons, and with typically more than 10 times the yield per weapon. One reason for the bloated number of weapons may be the competition between Russia and the United States and attempts to dominate the other so that a first strike might overwhelm the adversary (e.g., Lieber and Press 2006). In the case of a first strike, each missile of the adversary must be targeted with multiple warheads. The opponent must then obtain even more warheads so that it can attack each of the other country's missiles with more than one warhead. This competition to outnumber the other side leads to exponential growth in warheads. Alternative suggestions for the large numbers of weapons include competition for funding to support the nuclear infrastructure, political posturing, lack of planning or lack of thought about the size of the arsenal needed, or concern that there would be a high failure rate of the weapons.

Toon, Robock, and Turco (2008) analyzed a modern attack on the urban areas in a number of countries. They found that in an attack on US urban areas-based on population density, with 1,000 weapons of 100-kiloton yield - 48 percent of the US population would be within 5 kilometers of ground zero, 20 percent of the population (about sixty million people) would be killed outright, and another 16 percent injured (about forty million people). They also found that a war between India and Pakistan using fifty weapons with 15-kiloton yield on each country, exploded on cities based on population, would kill or injure about forty-five million people.

The eventual build-up to over 30,000 American warheads and 40,000 Soviet warheads, most with more than ten times the yield of the Hiroshima weapon, was gross overkill. There are simply not that many targets. It is supposed to be US policy to attack military and industrial targets, not civilian population centers. However, recently revealed nuclear targeting documents show that in 1959 population was treated as a distinct target for US nuclear weapons (Shane 2015). Yet, even this stance that population is not directly attacked is clearly misleading because military and industrial targets are both located in urban areas. For instance, Bush et al. (1991) and Small (1989) considered a counterforce attack by Russia on 3,030 leading US targets, such as US Army, Navy, and Air Force bases; fuel storage locations; refineries; and harbors (but not missile silos or launchcontrol facilities) with 500-kiloton warheads. ${ }^{2}$ In fact, due to the significant area

\footnotetext{
${ }^{2}$ In the lexicon of military targeting, there are countervalue, counterforce, and rational wars. Rational wars use a small number of weapons to attack targets of symbolic value. Countervalue wars use massive attacks on urban areas to destroy economic and social infrastructure. Counterforce wars
} 
destroyed by a nuclear bomb explosion, there were only 348 unique targets in these studies that were on average each attacked by 8.7 weapons when 3,030 weapons were used. While cities were not targeted directly, 50 percent of the US urban areas were destroyed.

There are only about 300 cities in the United States and 180 in Russia with a population greater than 100,000. There are about 60 cities in Pakistan, 365 in India, and 445 in China with a population greater than 100,000 . It might require more than one weapon to destroy some large cities, and there are some important targets in rural areas. Nevertheless, the 2,000 strategic deployed weapons in both the American and the Russian arsenals under current treaties still allows them to destroy the bulk of any adversary's infrastructure and population, given the likely assumption that the majority of the weapons detonate. The current arsenal of India is great enough to attack almost every moderate-sized city in Pakistan two times.

This sort of gruesome calculation of the numbers of weapons needed to destroy an adversary has likely been repeated in many nations. Based on the numbers of weapons in figures 1 and 3 , and the numbers of cities in the world that might be targets, the number of weapons is being chosen by most countries to ensure they can bomb every moderatesized city of any country in the world that they choose. The emphasis in sizing nuclear arsenals is on ensuring a level of destruction, not a level of survival.

Unfortunately, the collateral damage from using these weapons may be much greater than the direct damage. Therefore, ensuring the destruction of any adversary, and giving no consideration to how many might survive, may lead to the accidental deaths of most of the world's population.

\section{Self-Assured Destruction Following an Asian War}

Nuclear weapons cause damage through prompt and delayed nuclear radiation, thermal radiation, and shock waves. Prompt radiation comes from the nuclear fireball and the nuclear reactions producing the detonation. Delayed radiation comes from the fallout containing the radioactive daughter products of the nuclear explosion. Thermal radiation is a bright pulse of light emitted by the explosion. Shock waves are high winds and associated pressure fluctuations that occur over very short periods of time. It is difficult to untangle the direct damage from prompt radiation, thermal radiation, and shock waves because their zones of influence overlap near ground zero. Delayed radiation could kill large numbers of people in areas downwind of ground bursts, which might be used to attack missile silos. Ground bursts near the surface (as opposed to being deeply buried) lift relatively large soil particles into the air. Radioactive particles attach themselves to these dust particles, and when they fall out of the atmosphere onto the ground (hence the name "fallout") within hours or days, they can expose the population at the surface to dangerous levels of radiation. However, even

involve massive attacks on military, economic, and political targets. In reality, countervalue and counterforce wars end up attacking much the same targets, especially for large numbers of highyield weapons. 
with ground bursts, the casualties from delayed exposure to radiation are likely to be less than those from the other direct effects in an attack on a city. An attack on a missile silo, or other unpopulated area, might have the majority of casualties from delayed radiation. Airbursts are generally more destructive than ground bursts because the area impacted by prompt radiation, thermal radiation, and shock waves is larger. Therefore, combatants are likely to use airbursts unless they are attacking buried targets. The debris from airbursts generally contains little material of large enough size to fall out of the atmosphere quickly. Therefore, the nuclear radiation largely decays before it reaches the surface and is less of a hazard to people than material that falls out rapidly. If your goal is killing people, an airburst over a city is more effective than a ground burst that kills less with prompt radiation, thermal radiation, and shock waves and more with delayed radiation.

Following a nuclear explosion, the shock waves knock down structures. These ruptured buildings will experience myriad small fires, which can coalesce into a firestorm. The thermal radiation from the fireball can also set fires over a wide area. One does not need a nuclear weapon to initiate a firestorm. For example, the United States and its allies purposefully set many firestorms in urban areas during World War II, including at Dresden, Hamburg, Tokyo, and several other Japanese cities, using hundreds of aircraft carrying incendiary bombs. There have also been damaging firestorms after earthquakes, such as the 1906 San Francisco earthquake. It is believed that fires rather than the earthquake caused the vast majority of the damage to that city. The energy released in firestorms is immense. For instance, Toon et al. (2007) estimated that the energy released in the Hiroshima firestorm, which reached full strength several hours after the nuclear explosion, was about 1,000 times greater than the energy released in the nuclear explosion.

Firestorms are self-feeding fires that suck air into themselves and generate immense columns of rising smoke. There are many observations of stratospheric injections of smoke from large, intense forest fires, which are similar to urban firestorms (e.g., Fromm and Servranckx 2003). Once the smoke is 10 kilometers (6 miles) above the ground, sunlight will heat the smoky air and it will rise, which is called self-lofting. Observations may have recorded smoke from forest fires rising by self-lofting to 20 kilometers above the surface (de Laat et al. 2012), and models suggest large smoke injections in a nuclear conflict could reach 50 kilometers above the ground by self-lofting. At altitudes above 20 kilometers it never rains, so the smoke would remain in the air for years. The clouds from very large volcanic eruptions are observed to remain in the stratosphere for a few years, but they have only a small amount of self-lofting because their semitransparent particles do not absorb much sunlight.

The most recent study of the aftermath of a nuclear conflict (Mills et al. 2014) used an Earth system climate model including atmospheric chemistry, ocean dynamics, and interactive sea ice and land components to investigate the environmental damage from a limited, regional nuclear war between India and Pakistan. Mills et al. (2014) assumed each side detonates fifty weapons with 15 kilotons of yield for each weapon over urban areas. One hundred total weapons is about half of the existing arsenals of India and Pakistan. These urban explosions are assumed to start 100 firestorms, which would produce a total of slightly more than five million tons of smoke. In the computer simulation, this smoke self-lofted to the stratosphere, where it spread globally, producing a sudden drop in surface temperatures, because the smoke blocked sunlight from 
reaching the surface, and intense heating of the stratosphere, because the smoke absorbed sunlight. The results showed that about one-third of the smoke was removed after about nine years. In the hot stratosphere, ozone was destroyed by chemical reactions. Global ozone losses of 20-50 percent over populated areas, levels unprecedented in human history, would accompany the coldest average surface temperatures since the waning phases of the last ice age, thousands of years ago. Ozone in the stratosphere protects us from the harmful effects of solar ultraviolet light. Mills et al. (2014) calculated summer enhancements in ultraviolet solar exposure indices of 30-80 percent over midlatitudes, suggesting widespread damage to human health, agriculture, and terrestrial and aquatic ecosystems, though the effects of enhanced ultraviolet light are poorly understood since such enhancements have never been observed. Killing frosts would reduce growing seasons by ten to forty days per year for five years at mid-latitudes. Surface temperatures would be reduced for more than twenty-five years. The long period of cold temperatures is due to thermal inertia from the cooled ocean waters and to extra reflection of sunlight back to space by expanded sea ice.

Large global decreases in ozone have not been observed in human experience, though there is a significant latitudinal gradient in ultraviolet intensity. It is known, for instance, that the incidence of skin cancer in people with light-colored skin increases with decreasing latitude as a result of increasing ultraviolet light. The ultraviolet light is greatest in the tropics because the sun is more intense there and because there is less ozone in the tropics than elsewhere. While we know that enhanced ultraviolet light is hazardous, its effects are not included in agricultural models, so it is not possible to gauge its impact on food supplies or the environment. On the other hand, we have a lot of experience with the effects of changes in temperature and precipitation on agriculture. Table 1 provides some calculated crop losses due to temperature and precipitation changes following a regional war with 100 weapons. The crop declines are mainly due to reduced temperatures and shortened growing seasons.

There are no studies on the effect on human society of crop losses such as those shown in table 1. However, there are several reasons to think the effects would be devastating. The world does not recognize the Biblical warning by Joseph to the Pharaoh of Egypt to store grain for seven years of famine. Instead, the total world grain storage would be consumed in around seventy days at the current rate of consumption (see

Table 1. Loss of agricultural productivity following a regional nuclear conflict with 100 warheads (Özdoğan et al. 2013; Xia and Robock 2013; Xia et al. 2015).

\begin{tabular}{lcc}
\hline & First Five Years & Second Five Years \\
\hline US maize & $-20 \%$ & $-10 \%$ \\
US soybeans & $-15 \%$ & $-10 \%$ \\
China maize & $-15 \%$ & $-12 \%$ \\
China middle-season rice & $-26 \%$ & $-21 \%$ \\
China spring wheat & $-26 \%$ & $-20 \%$ \\
China winter wheat & $-38 \%$ & $-23 \%$
\end{tabular}




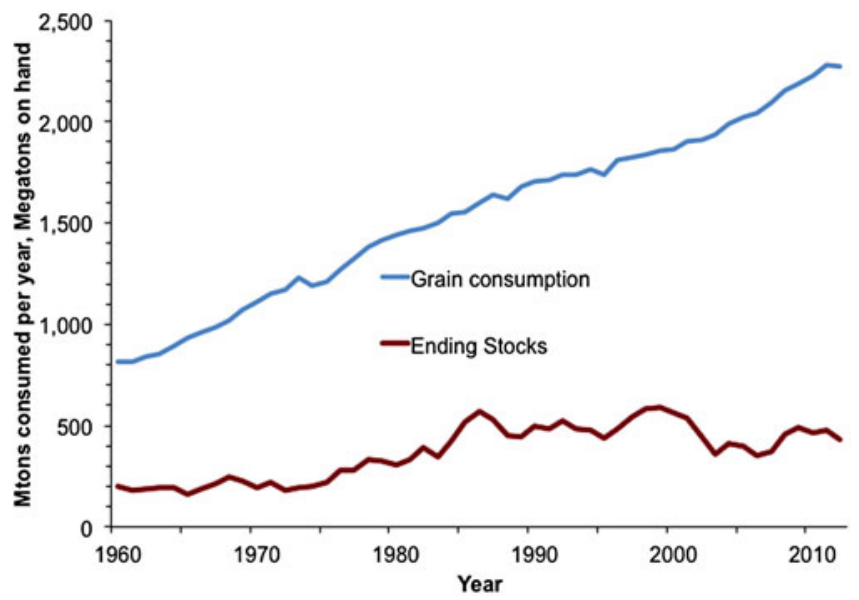

Figure 5. The worldwide consumption of grains and the ending stocks from 1960 until 2012. Data from Earth Policy Institute (2012).

figures 5 and 6). As shown in figure 5, consumption has steadily risen since 1960 as world population increased, but ending food stocks, which represent food storage, have leveled out since about 1985. Food production and consumption are closely balanced, and the food surplus or deficit is a small fraction of ending stocks (less than 23 percent) in the past fifty years, as shown in figure 6. The small ups and downs of the ending stocks curve in figure 5 represent the accumulation of the year-to-year variations in the production of grains relative to their consumption. Recently food consumption has tended to exceed production slightly, so ending stocks are slowly trending downward in figure 5 . Given the rising population, the days of food on hand has declined by about a factor of two in the past decade to less than seventy days at present, as shown in figure 6 .

Table 1 suggests, from the limited studies done so far, that a regional nuclear conflict between India and Pakistan might reduce global grain production by 20 percent for five years and 10-15 percent for another five years. A 20 percent reduction in grain production today would represent about 450 metric tons of grain each year, which is comparable to the ending stocks on hand in 2012. This would be an unprecedented loss of food, exhausting the global food storage in one year, and could not be made up, since the loss would continue for a decade.

How would the world respond to a sudden global decline in food? Some clues are given in figure 7 , which illustrates an inflation-corrected food price. The Food Price Index is an estimate of the relative costs of meat, dairy, grains, oils, and sugar. Historically the highest price was in the early 1970s, which corresponds to a time when figure 6 indicates there was a minimum of days of food consumption near fifty-six days. We are currently experiencing a new period of a relatively high Food Price Index with peaks in 2008 and 2011 and a new minimum of days of food consumption.

Analysis of the 1970 s peak in the price of food indicates that a major cause was a drop in agricultural production, particularly in Russia, that was partly compensated by the United States selling Russia the equivalent of 30 percent of the US wheat production in the previous few years. The food price jump was exacerbated by decisions made by 


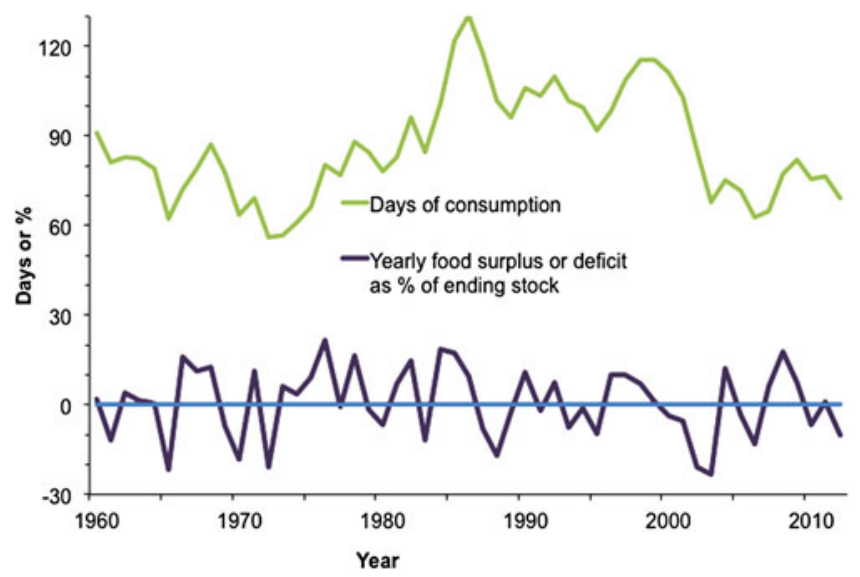

Figure 6. The number of days that the ending stocks could supply world food consumption, and the surplus or deficit of food as a percentage of the ending stocks. Data from Earth Policy Institute (2012).

various political bodies (e.g., Schnittker 1973). Although apparently unrelated in cause, the Arab oil embargo coincided in time and drove energy prices to record levels, causing rationing and other disruptions across the globe.

The 2008 food price peak followed another low point in the days of food consumption near sixty-three, and another run-up in energy prices. These changes were coupled with the increased use of biofuels, which diverted about 100 million tons of maize away from food; wheat-growing failures in Australia; an increased consumption of meat in

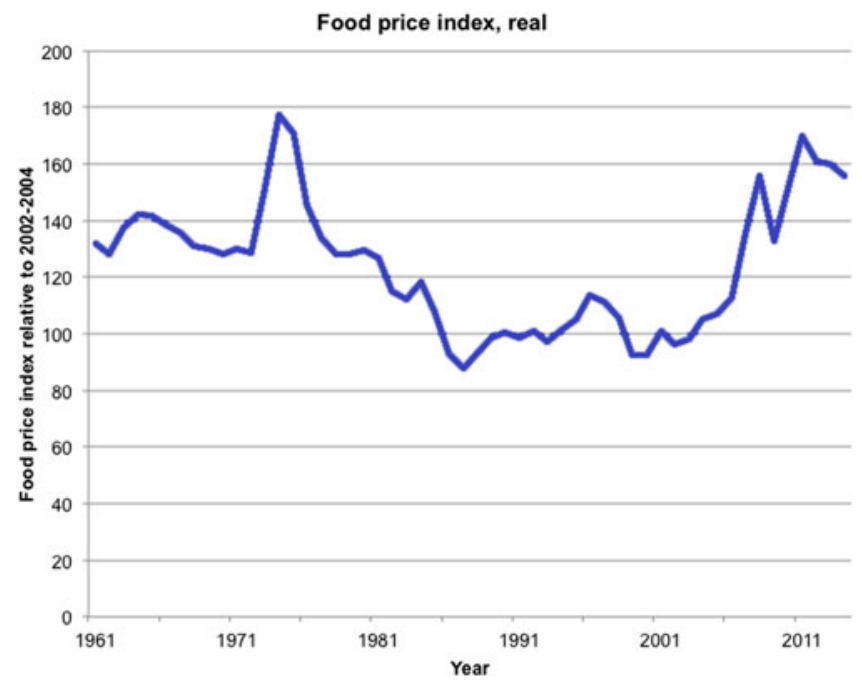

Figure 7. UN Food and Agriculture Food Price Index, based on data from Earth Policy Institute, Monthly Food Price Indexes, January 1990-January 2014, updated February $6,2014$. 
China; and various types of speculation and political manipulation. In the case of rice, India and Vietnam stopped exporting rice, which may have been due to internal political manipulations in India and speculation in Vietnam. The loss of two of the world's largest rice exporters caused a cascade of panic in rice-importing nations (Slayton 2009). Whatever the cause, the rise in food prices coincided with food riots in a number of countries and significant numbers of deaths in those riots (Lagi, Bertrand, and Bar-Yam 2011). The government of Haiti was overthrown in 2008 during food-related riots, and there were bread riots in Egypt in 2008 (Sternberg 2013).

The 2011 spike in the Food Price Index may have had even more dramatic impacts on world affairs. In 2010, Russian wheat production fell 32.7 percent, Ukrainian wheat production fell 19.3 percent, Canadian wheat production fell 13.7 percent, and Australian wheat production fell 8.7 percent (Sternberg 2013). In the fall of 2010, China experienced drought and began to purchase wheat, which drove up prices. People in Middle Eastern and North African countries spend large fractions of their income on food. Libya, Jordan, Algeria, Tunisia, Yemen, and Egypt are each in the range of 35-44 percent of income spent on food. A large fraction of the food is bread. A significant causal factor in the Arab Spring uprisings, beginning in December 2010 and still ongoing today, was food insecurity due to the wheat failures in 2010 (Sternberg 2013). Since 2010, rulers have been forced out of power in Tunisia, Egypt, Libya, and Yemen. There have been uprisings in Bahrain and Syria, and major protests in Algeria, Iraq, Jordan, Kuwait, Morocco, and Sudan.

The production failures in recent decades pale in comparison to those that might follow a nuclear conflict between India and Pakistan. In that case, the world grain storage might be eliminated in the first year after a war, and a deficit of 10-20 percent might then occur for a decade. Helfand (2013) has estimated that two billion people who are now only marginally fed might die from starvation and disease in the aftermath of a nuclear conflict between India and Pakistan. A conflict in the future with more weapons, or between other powers with more weapons, could be much worse.

\section{SCENARIOS FOR WAR}

People have grown comfortable with nuclear weapons, and few are concerned about the possibility of nuclear conflict. Unfortunately, this lack of concern is not justified by the facts. We are only an accident, a mistake, or a deranged politician away from killing most of the world's population now. As arsenals continue to grow, the threat of a nuclear exchange is bound to grow in the future.

The United States and Russia remain in "launch on warning status" which means that the leaders of these countries are constantly prepared to launch some of their nuclear missiles within a few moments of learning that missiles from the other side are headed their way. This is a very dangerous situation. There are numerous examples of each side mistakenly thinking the other has initiated an attack, and war has been narrowly averted by identifying or discounting the mistake.

In Asia, a number of analyses have been conducted of how a war might start. For instance, Lavoy and Smith (2003) discuss three plausible scenarios for a nuclear war between India and Pakistan. India has conventional military superiority. India is also 
geographically much larger than Pakistan, so parts of its nuclear arsenal are currently out of range of Pakistan's forces, while all of Pakistan is easily reached from India. One possible route to nuclear war involves a conventional conflict between India and Pakistan. If Pakistan perceived that India were about to invade, that could put pressure on Pakistan to launch its nuclear weapons before it was overrun by the superior Indian forces. Another possibility for starting a nuclear conflict is that India or Pakistan could lose control of its command and control structures due to an attack on it by the other side, or possibly an attack by terrorists. In such a scenario, it is not clear who might be in control of the nuclear forces and what steps they might take. A third possibility for starting a nuclear conflict is that India or Pakistan might mistake an attack by conventional forces, or even military exercises, for an attack by nuclear forces. Both countries have ballistic missiles and aircraft that are potentially dual-use between conventional and nuclear weapons, making any attack ambiguous.

Another point of future conflict could involve North Korea. It is not clear that North Korea currently has operational nuclear weapons, though it has tested nuclear explosives. It is also not certain that North Korea has nuclear-capable missiles (Kristensen and Norris 2014), though it continues to test long-range missiles and submarine-launched missiles and does have nuclear-capable aircraft. Fortunately, no other countries with nuclear weapons are near North Korea, except for China, with which North Korea is allied. Factors that might trigger a nuclear conflict involving North Korea have some parallels with the Pakistan/India situation. North Korea has a much larger military than South Korea, including the US troops stationed in South Korea, and Seoul is only thirty-five miles from the North Korean border. It would, therefore, be possible for North Korea to overrun South Korea in a sudden attack, possibly triggering a nuclear attack by the United States. Hayes and Cavazos (2015) have analyzed some of the many possible scenarios for a nuclear conflict involving North Korea. Generally they conclude that North Korea does not have the capability to launch an attack at present, but may have in the near future. While North Korea is expanding its capabilities, it is difficult to find a scenario in which it could launch a first-strike nuclear conflict and win, even in the future. However, the North Koreans may not analyze the situation in the same ways that are done in the West: their leadership might not be rational; there is the potential for the regime to be overthrown, leading to nuclear weapons use in North Korea itself; and it is possible that its continuing provocations of its neighbors might lead to an attack on North Korea. Any of these possibilities, and several others, might lead to the use of nuclear weapons.

There are numerous other scenarios that could lead either to a nuclear conflict or to destabilizing Asia further. For example, Japan or South Korea could develop nuclear weapons to defend against North Korea, likely because they lose confidence that the United States will continue to protect them. Iran could obtain nuclear weapons, which would likely trigger Saudi Arabia and other countries in the Middle East to obtain them. Hopefully, the 2015 agreement with Iran will prevent the Middle East from becoming a warren of nuclear states.

Unless the world does something to build-down the existing arsenals further, and stops proliferation, the remainder of the twenty-first century is likely to involve increasing risk of nuclear confrontations. 


\section{What Can Asian Countries Do?}

No government, anywhere, is conducting studies to determine the damage that might be done to them in a nuclear conflict in which they were a combatant, or a bystander. There is no evidence that any current leader of any nuclear power is aware of the potential harm that might occur due to the environmental damage from a nuclear conflict. However, the cold temperatures and the destruction of the ozone layer caused by the smoke from burning cities following a nuclear conflict, even between powers such as India and Pakistan with modest numbers of weapons compared with other Nuclear Weapons States, could devastate agricultural productivity, leading to mass starvation across the globe. It is dangerous not to discuss these issues and risks openly in society.

Calculating the direct casualties from a nuclear conflict is very straightforward. The major uncertainties are the number and yields of the weapons used and their targets. There is also uncertainty about extrapolating the casualties from Hiroshima and Nagasaki to those that would occur in modern cities at various distances from ground zero. It is more difficult to compute the environmental impacts from nuclear conflicts and their consequences. However, the major uncertainties are the same for the direct effects, the number and yields of the weapons used, and their targets. The size and duration of resulting firestorms is uncertain, since we have no modern examples. In addition, the amount of fuel burned, the amount of smoke emitted, and the amount of smoke removed in local precipitation are uncertain. Uncertainty does not mean that the impacts have been overestimated. It is just as likely that the effects have been underestimated. Like many other areas of human endeavor, uncertainty is unavoidable when predicting the outcome of possible nuclear wars. However, when gambling with the future of human civilization, it is not wise to ignore the possibility of nuclear winter by hoping that no country will ever use its arsenal.

Donna Goldstein argues in this volume that politicians do not care about the predictions of models, and use science only to manipulate events. However, the Montreal Protocol, which is based on modeling showing that the release of certain chemicals is destroying the ozone layer, has reduced industrial emissions of ozone-destroying chemicals. The Intergovernmental Panel on Climate Change, which is largely based on models for future climate, is currently pushing a revision of the Earth's energy production system. These are very large changes caused by scientific recognition of a problem, and wrought by statespersons who have taken science very seriously. Of course, in both these examples there was also evidence that the Earth was being impacted, such as the Antarctic ozone hole, melting glaciers, rising sea levels, and rising temperatures. Nuclear war is not approachable by experiment or observation. Nevertheless, there is no reason to be pessimistic and assume that politicians cannot understand the advice about the dangers of nuclear wars from their scientific establishments, or will not act on that advice. History shows, even in the case of nuclear weapons, that statespersons will understand these dangers if they are told of them, and act appropriately.

In the early 1980s, studies of the environmental effects of a nuclear conflict played a role in causing the leaders of the United States and of the Soviet Union to reduce their arsenals. Mikhail Gorbachev observed, "Models made by Russian and American scientists showed that a nuclear war would result in nuclear winter that would be extremely 
destructive to all life on Earth: the knowledge of that was a great stimulus to us, to people of honor and morality, to act" (Hertsgaard 2000). And Ronald Reagan noted:

[A] great many reputable scientists are telling us, that such a war could just end up in no victory for anyone because we would wipe out the earth as we know it. And if you think back to ... natural calamities - back in the last century, in the 1800 's, ... volcanoes - we saw the weather so changed that there was snow in July in many temperate countries. And they called it the year in which there was no summer. Now if one volcano can do that, what are we talking about with the whole nuclear exchange, the nuclear winter that scientists have been talking about? It's possible. (New York Times 1985)

As a first step toward a world that is free of the threat of a global nuclear catastrophe, we suggest that the nuclear-armed states, perhaps led by those in Asia, collectively engage in a dialog on the impacts of nuclear conflicts. There is precedence for such a dialog in two formats. Just prior to the build-down in nuclear weapons illustrated in figure 1 and the pause in the creation of new nuclear states illustrated in figure 2, the scientific academies of the world conducted a study of nuclear conflicts under the umbrella of the UN Scientific Committee on Problems of the Environment (Harwell and Hutchinson 1986; Pittock et al. 1986). Of course, it is not just scientists that need to participate in this discussion, as discussed by Yeh in this volume. During the early 1980s, a vibrant debate about nuclear weapons took place among a wide variety of interest groups, including physicians, politicians, philosophers, and poets. More recently, an environmental disaster was avoided when the nations of the world agreed to limit ozone-destroying chemicals in the Montreal Protocol on Substances that Deplete the Ozone Layer. Currently the Intergovernmental Panel on Climate Change is working to achieve international agreement on regulations related to climate change. We suggest that there be a new study of the consequences of nuclear conflict.

The study should not only consider the consequences of conflicts, but should also address whether the reasons cited to develop nuclear weapons are valid. For example, Japan and South Korea do not have nuclear arsenals, while North Korea does. There is no evidence that North Korea is technologically superior in any way, has a greater place in any facet of world decision-making, or has a greater influence on any aspect of world affairs. Nor is North Korea any safer due to nuclear technology. The same opposing army is still in South Korea that was there prior to North Korea testing nuclear weapons. Indeed, sanctions placed on North Korea because of its nuclear weapons program, which may not have impacted its nuclear weapons program, have damaged its economy. Likewise, India has not gained entry to the UN Security Council because of its nuclear arsenal, and while India is recognized for its many prominent scientists and thinkers in a variety of peaceful fields of study, its nuclear program has done nothing to gain it respect as a technological power in the rest of the world. Pakistan's nuclear weapons have not helped it solve its dispute with India over Kashmir, nor has it prevented other nations from bombing its citizens and making armed military raids to seize militants located in its territories.

India and Pakistan are engaged in a rapid build-up of nuclear weapons, which is a danger to them both and to the rest of the world. While dialogs between these 
nations, and others, have taken place for decades, little progress has been made. Possibly a detailed analysis by their own scientists and scientists of other nations of the consequences of a war would aid them in constructive discussions. Of course, these studies should include an analysis of conflicts involving all the nuclear-armed nations and consider all of their arsenals.

History shows that nuclear weapons do not achieve the goals envisioned by the states that have them. Not even a single nuclear weapon can be used, given the potential for escalation to employ many more weapons, leading to a nuclear winter. Such escalation is particularly likely due to the 1,800 weapons on high alert in the United States and Russia that could be used on short notice. A nuclear war cannot be fought, given the adverse impacts on the food supply of all nations of the world, including the ones that used them. The case of Pakistan's invasion of Kashmir after its test of nuclear weapons, and the entire Cold War, show that nuclear arsenals do not provide cover for unopposed conventional warfare. The Argentinean invasion of the Falklands and the Yom Kippur War show that possession of nuclear weapons does not stop invasions of nuclear nations by non-nuclear nations. The Vietnam War and the Soviet war in Afghanistan show that nuclear weapons do not help win wars, since in both wars the nuclear power lost. The weapons do not confer immunity from meddling by others in internal affairs, nor give countries with them enhanced access to world government. On the contrary, the weapons are very expensive to obtain and maintain. The weapons expose their possessors, and the rest of the world, to the potential for terrorists to obtain and use them. There is a significant risk, particularly between India and Pakistan, of nuclear conflict starting from misunderstanding, or misinterpretation of the other country's actions. A large fraction of the world's population, inside and outside of the combat zone, could die from such errors. It would behoove each Nuclear Weapons State, in Asia and elsewhere, to get rid of its nuclear weapons before it is too late.

\section{Acknowledgments}

Alan Robock and Lili Xia are supported by National Science Foundation grants AGS-1157525 and GEO-1240507.

\section{List of References}

Bush, Brian W., M. A. Dore, G. H. Anno, and Richard D. Small. 1991. "Nuclear Winter Source-Term Studies: Smoke Produced by a Nuclear Attack on the United States." Report no. DNA-TR-86-220-V6, 6. Alexandria, Va.: Defense Nuclear Agency.

De Laat, Jos, Debora C. Stein-Zweers, Reinout Boers, and Olaf N. E. Tuinder. 2012. "A Solar Escalator: Observational Evidence of the Self-Lofting of Smoke and Aerosols by Adsorption of Solar Radiation in the February 2009 Australian Black Saturday Plume." Journal of Geophysical Research 117(D4). doi:10.1029/2011JD017016.

Earth Policy Institute. 2012. "World Grain Consumption and Stocks as Days of Consumption, 1960-2012." http://www.earth-policy.org/data_center/C24 (accessed May 24, 2014). 
Eden, Lynn. 2004. Whole World on Fire: Organizations, Knowledge, and Nuclear Weapons Devastation. Ithaca, N.Y.: Cornell University Press.

Evans, Gareth. 2014. "Nuclear Deterrence in Asia and the Pacific." Asia and the Pacific Policy Studies 1(1):91-111. doi:10.1002/app5.00011.

Fromm, Michael D., and Rene Servranckx. 2003. "Transport of Forest Fire Smoke above the Tropopause by Supercell Convection." Geophysical Research Letters 30 (10). doi:10.1029/2002GL016820.

Harwell, Mark A., and Thomas C. Hutchinson. 1986. Environmental Consequences of Nuclear War: Volume II: Ecological and Agricultural Effects. New York: Wiley.

Hayes, Pete, and Roger Cavazos. 2015. "North Korea’s Nuclear Force Roadmap: Hard Choices." NAPSNet Special Reports, March 2. http://nautilus.org/napsnet/ napsnet-special-reports/north-koreas-nuclear-force-roadmap-hard-choices (accessed January 6, 2017).

Helfand, Ira. 2013. Nuclear Famine: Two Billion People at Risk? 2nd ed. Malden, Mass.: International Physicians for the Prevention of Nuclear War. http:/www.ippnw.org/ pdf/nuclear-famine-two-billion-at-risk-2013.pdf (accessed May 24, 2014).

Hertsgaard, Mark. 2000. "Mikhail Gorbachev Explains What's Rotten in Russia." Salon, September 7. http://www.salon.com/2000/09/07/gorbachev/ (accessed May 28, 2014).

Kothari, Smitu, and Zia Mian, eds. 2001. Out of the Nuclear Shadow. London: Zed Books.

Kristensen, Hans M., and Robert S. Norris. 2013. "Global Nuclear Weapons Inventories, 1945-2013." Bulletin of the Atomic Scientists 69(5):75-81. doi:10.1177/ 0096340213501363.

—. 2014. "Worldwide Deployments of Nuclear Weapons, 2014." Bulletin of the Atomic Scientists 70(5):96-108. doi:10.1177/0096340214547619.

Lagi, Marco, Karla Z. Bertrand, and Yaneer Bar-Yam. 2011. "The Food Crises and Political Instability in North Africa and the Middle East.” https://arXiv.org/pdf/ 1108.2455 (accessed May 28, 2014).

Lavoy, Peter R., and Stephen A. Smith. 2003. "The Risk of Inadvertent Nuclear Use Between India and Pakistan." Strategic Insight, February 3. http://www.dtic.mil/ dtic/tr/fulltext/u2/a525408.pdf (accessed May 18, 2015).

Lieber, Keir A., and Daryl G. Press. 2006. "The Rise of U.S. Nuclear Primacy." Foreign Affairs, March/April. http://www.foreignaffairs.com/articles/61508/keir-a-lieber-anddaryl-g-press/the-rise-of-us-nuclear-primacy (accessed May 28, 2014).

Mills, Michael J., Owen B. Toon, Julia Lee-Taylor, and Alan Robock. 2014. "Multidecadal Global Cooling and Unprecedented Ozone Loss Following a Regional Nuclear Conflict." Earth's Future 2(4):161-76. doi:10.1002/2013EF000205.

NEW YORK TIMEs. 1985. "Transcript of Interview with President on a Range of Issues." February 12. http://www.nytimes.com/1985/02/12/world/transcript-of-interviewwith-president-on-a-range-of-issues.html (accessed May 28, 2014).

Nuclear Security Project. n.d. "Wall Street Journal Op-Eds.” http://www.nuclearsecurityproject.org/publications/wall-street-journal-op-eds (accessed May 28, 2014).

ÖzdoĞan, Mutlu, Alan Robock, and Christopher Kucharik. 2013. "Impacts of a Nuclear War in South Asia on Soybean and Maize Production in the Midwest United States." Climatic Change 116(2):373-87. doi:10.1007/s10584-012-0518-1.

Pittock, A. Barrie et al. 1986. Environmental Consequences of Nuclear War: Volume I: Physical and Atmospheric Effects. New York: Wiley. 
Robock, Alan, and Owen B. Toon. 2012. "Self-Assured Destruction: The Climate Impacts of Nuclear War." Bulletin of the Atomic Scientists 68(5):66-74.

SAGAN, ScotT D. 2012. "Policy: A Call for Global Nuclear Disarmament." Nature 487 (7405):30-32.

SarDesai, Damodar R., and Raju G. C. Thomas, eds. 2002. Nuclear India in the TwentyFirst Century. New York: Palgrave Macmillan.

Schnittker, John. 1973. "The 1972-73 Food Price Spiral.” Brookings Papers on Economic Activity 2:498-507.

Shane, Scott. 2015. “1950s U.S. Nuclear Target List Offers Chilling Insight.” New York Times, December 22. http://www.nytimes.com/2015/12/23/us/politics/1950s-usnuclear-target-list-offers-chilling-insight.html (accessed February 1, 2016).

Shultz, George P., William J. Perry, Henry A. Kissinger, and Sam Nunn. 2007. “A World Free of Nuclear Weapons." Wall Street Journal, January 4. http://online. wsj.com/article/SB116787515251566636.html (accessed May 28, 2014).

— . 2008. “Toward a Nuclear-Free World.” Wall Street Journal, January 15. http:// online.wsj.com/article/SB120036422673589947.html (accessed May 28, 2014).

— _ 2010. "How to Protect Our Nuclear Deterrent." Wall Street Journal, January 19. http://online.wsj.com/article/SB10001424052748704152804574628344282735008. html (accessed May 28, 2014).

— 2011. "Deterrence in the Age of Nuclear Proliferation." Wall Street Journal, March 7. http://online.wsj.com/article/SB10001424052748703300904576178760530169414. html (accessed May 28, 2014).

Slayton, Tom. 2009. "Rice Crisis Forensics: How Asian Governments Carelessly Set the World Rice Market on Fire.” CGD Working Paper 163. Washington, D.C.: Center for Global Development. http://www.cgdev.org/content/publications/detail/1421260/ (accessed January 6, 2017).

Small, Richard D. 1989. “Atmospheric Smoke Loading from a Nuclear Attack on the United States.” Ambio 18(7):377-83.

Sternberg, Troy. 2013. "Chinese Drought, Wheat, and the Egyptian Uprising: How a Localized Hazard Became Globalized.” In The Arab Spring and Climate Change: A Climate and Security Correlations Series, eds. Caitlin E. Werrell and Francesco Femia. Center for American Progress. http://americanprogress.org/issues/security/report/2013/02/28/ 54579/the-arab-spring-and-climate-change/ (accessed May 28, 2014).

Toon, Owen B., Alan Robock, and Richard P. Turco. 2008. "Environmental Consequences of Nuclear War.” Physics Today 61(12):37-42. doi:10.1063/1.3047679.

Toon, Owen B., Richard P. Turco, Alan Robock, Charles Bardeen, Luke Oman, and Georgiy L. Stenchikov. 2007. "Atmospheric Effects and Societal Consequences of Regional Scale Nuclear Conflicts and Acts of Individual Nuclear Terrorism." Atmospheric Chemistry and Physics 7:1973-2002.

XIA, LiLi, and Alan Robock. 2013. "Impacts of a Nuclear War in South Asia on Rice Production in Mainland China." Climatic Change 116(2):357-72. doi:10.1007/ s10584-012-0475-8.

Xia, Lili, Alan Robock, Michael Mills, Andrea Stenke, and Ira Helfand. 2015. "Decadal Reduction of Chinese Agriculture after a Regional Nuclear War." Earth's Future 3(2):37-48. doi:10.1002/2014EF000283. 